Int. J. Electrochem. Sci., 12 (2017) $8991-9006$

International Journal of

ELECTROCHEMICAL

SCIENCE

www.electrochemsci.org

\title{
Corrosion Behavior of 316L Stainless Steel Coated by Chitosan/Gold/Nickel Nanoparticles in Mixed Acid Mixture Containing Inorganic Anions
}

\author{
Reham H. Tammam* ${ }^{*}$ Amany M. Fekry \\ Chemistry Department, Faculty of Science, Cairo University, Giza-12613, Egypt. \\ *E-mail: reham_tammam@cu.edu.eg
}

doi: $10.20964 / 2017.10 .74$

Received: 3 July 2017 / Accepted: 12 August 2017 / Published: 12 September 2017

The electrochemical behavior of 316L stainless steel alloy was performed by open circuit potential, electrochemical impedance spectroscopy, potentiodynamic polarization measurements and surface examination using scanning electron microscope technique in phosphoric and sulphuric acid solution mixtures with different percentages. The effects of inorganic additives (fluoride and iodide) on the corrosion of the tested alloy in mixed acidic mixture were also done. It was found that the corrosion rate decreases in the acidic mixture solution containing iodide than fluoride ion. However, electrodeposition of chitosan/Gold nanoparticles (AuNPs)/nickel nanoparticles (NiNPs) protects well the alloy surface in the most corroded solution of $0.005 \mathrm{M} \mathrm{NaF}$. The efficiency increases according to the following order: coating $>\mathrm{I}^{-}>\mathrm{F}^{-}>$blank mixed acidic mixture. EIS results are in decent arrangement with polarization and open circuit potential results. All results are confirmed with surface examination.

Keywords: 316L stainless steel; coating; EIS, SEM and nanoparticles.

\section{$\underline{\text { FULL TEXT }}$}

(C) 2017 The Authors. Published by ESG (www.electrochemsci.org). This article is an open access article distributed under the terms and conditions of the Creative Commons Attribution license (http://creativecommons.org/licenses/by/4.0/). 